\title{
MOVEMENTS OF JUVENILE GYRFALCONS FROM WESTERN AND INTERIOR ALASKA FOLLOWING DEPARTURE FROM THEIR NATAL AREAS
}

\author{
Carol L. Mclntyre ${ }^{1}$, David C. Douglas ${ }^{2}$, and Layne G. Adams ${ }^{3}$ \\ ${ }^{1}$ US National Park Service, Denali National Park and Preserve, 4175 Geist Road, \\ Fairbanks, AK 99709,USA. E-mail: carol_mcintyre@nps.gov \\ ${ }^{2}$ US Geological Survey, Alaska Science Center, Juneau Office, 3100 National Park Road, \\ Juneau, AK 99801, USA \\ ${ }^{3}$ US Geological Survey, Alaska Science Center, 4210 University Drive, \\ Anchorage, AK 99508, USA
}

\begin{abstract}
EXTENDED ABstRaCT.-Birds are highly mobile organisms and their spatial and temporal movement patterns are among the most diverse among vertebrates (Welty 1963, Alerstam 1990, Newton 2008). Some individuals remain relatively close to their natal nest throughout their entire lives, whereas others may travel thousands of kilometers annually, starting with their initial movements away from their natal nests (Newton 2008). Juvenile raptors exhibit a wide range of movement patterns (Newton 1979), with individuals originating in high latitudes often traveling thousands of kilometers across different habitats and often across international boundaries within their first year of life (McGrady et al. 1997, McIntyre et al. 2008). Documenting the year-round movements and identifying the areas used by raptors before they enter a breeding population is important for understanding the factors that influence their survival (Steenhof et al. 2005). Further, because juvenile raptors often experience higher rates of mortality than older age classes (Newton 1979), locating the areas used by juveniles immediately after they leave their natal areas is important for identifying factors that affect their survival.
\end{abstract}

Gyrfalcons (Falco rusticolus) are one of the least studied raptor species in North America, owing in part to their low nesting density in remote northern areas and their dispersed and often remote wintering areas (Booms et al. 2008). In North America, Gyrfalcons are considered partial or irregular migrants (Kerlinger 1989, Booms et al. 2008). Birds remaining on their territories during winter are almost exclusively adults (Booms et al. 2008); however, the sample size of observations of Gyrfalcons on their nesting territories in winter in North America is extremely small. Little is known about the year-round movements of Gyrfalcons. Individuals are regularly observed south of their breeding range during winter (Booms et al.2008), but the origin of these individuals is rarely known. Encounters of seven Gyrfalcons banded as nestlings in Canada and Alaska showed that some juveniles moved long distances away from their natal areas $(>2500 \mathrm{~km}$; Schmutz et al. 1991), with one individual from Alaska completing a transoceanic and transcontinental flight between Alaska and eastern Russia (Kessel 1989). 
Here we describe the movements of juvenile Gyrfalcons from western and interior Alaska during the first few months of their independence as derived from a satellite telemetry study. Our study areas were in the Highland region foothills (Kessel 1989) of the central Seward Peninsula $\left(65.6^{\circ} \mathrm{N}, 165.0^{\circ} \mathrm{W}\right)$ in western Alaska and in the northern foothills of the Alaska Range in Denali National Park and Preserve (Denali) in central Alaska $\left(63.5^{\circ} \mathrm{N}\right.$, $\left.149.7^{\circ} \mathrm{W}\right)$. Both study areas contained relatively high densities of nesting Gyrfalcons (Swem et al. 1994).

We used aerial surveys to locate Gyrfalcon nests on the Seward Peninsula and obtained Gyrfalcon nest locations in Denali from ongoing raptor studies. We radio-tagged Gyrfalcons within 10 days of their estimated fledging dates. We estimated the age of nestlings on the day that we radio-tagged them based on their size and feather development. We backdated from the estimated age at radio-tagging to estimate hatch date, and added 50 days (fledging age; Poole and Bromley 1988) to the hatch date to predict fledging dates. We entered nests using standard rock climbing techniques and instrumented nestlings with lightweight satellite transmitters (PTTs) (Microwave Telemetry, Columbia, Maryland, USA) that weighed $3 \%$ of the mass of the nestling at deployment. PTTs were powered by lithium batteries and transmitted (duty cycle) for $6 \mathrm{~h}$ every 72 to 120 h. Battery life was estimated at approximately one year (P. Howey pers. comm.). See McIntyre et al. (2009) for a complete description of the radio tagging methods. The entire radiopackage, including harness, was within the conventional guidelines for telemetric studies of birds (Caccamise and Hedin 1985).

We deployed five 48-g PTTs on the Seward Peninsula in 1992, seven 31-g PTTs on the Seward Peninsula in 1993, and eight 31-g PTTs in Denali in 1995. Four PTTs failed and one Gyrfalcon tore off its harness before it left the natal area, resulting in a tracking sample size of 15 Gyrfalcons that successfully departed their natal areas with functioning PTTs. We obtained locations of radio-tagged Gyrfalcons using the Argos Data Collection and Location System (Argos 1996). We obtained 1664 relocations including 374 standard-class locations ( $\mathrm{LC}=3,2$, and 1 ) and 1290 auxiliary-class locations ( $\mathrm{LC}=0, \mathrm{~A}, \mathrm{~B}$, and $\mathrm{Z}$ ) and used a hybrid filtering strategy developed by Douglas (2006) that evaluated the Argos auxiliary locations based on two independent methods (see McIntyre et al. 2009 for details).The resulting filtered data set of "best" LC locations per duty cycle contained 347 records including 210 standard locations and 137 auxiliary locations and was used for all analyses presented in this paper. We did not retrieve motionless PTTs and do not know the final fate of the radio-tagged birds. Based on data from an internal PTT activity sensor, we categorized a PTT as a "mortality/shed harness" if it remained motionless for $>2$ consecutive duty cycles unless subsequent movement data indicated otherwise and a PTT as a "radio failure" if we lost radio contact with it within its expected battery life span.

We defined the natal area as the area within a $10-\mathrm{km}$ radius of the natal nest. Because of our $\geq 3$-days duty cycle, we could not determine the actual dates of departure from the natal area; hence, we estimated departure date from the natal area as the midpoint date between the last date when the radio-tagged Gyrfalcon was in its natal area and the first date that it remained permanently out of it. We calculated total distance moved during the tracking period as the cumulative tracking distance $(\mathrm{km})$; however, we recognized that these were minimum estimates since our tracking was not continual and movements were certainly not strictly linear between locations acquired in consecutive duty cycles.

We generated summary statistics of the spatial and temporal parameters of Gyrfalcon movements during six successive 2 -week tracking periods after they permanently departed their natal areas (the post-departure period). We 
adopted this approach because we were most interested in examining patterns of movements among birds, our sample size of radio-tagged birds decreased during the study period, and our tracking period was relatively short. We report vector lengths as orthodromes ("great circle" routes) and their azimuths as true bearing from the departure location. We used Watson's $U^{2}$ to test for differences in mean post-departure bearings and ANOVA to test for differences in mean distances moved by Gyrfalcons from the Seward Peninsula and Denali during six successive 2 -week periods postdeparture. Means and medians are presented \pm standard deviation (SD), unless otherwise noted. We performed statistical analyses using Oriana software (Kovach 2003) and S-Plus Version 6.1 (Insightful 2001) and we used an $\alpha$-level of 0.05 for all tests.

Gyrfalcons spent an average of $41.4 \pm 6.1$ days (range $=30-50$ days) in their natal areas after fledging. The length of the post-fledging period and timing of dispersal were similar among radio-tagged birds and were similar to estimates ( 28 to 56 days) reported by Nielsen and Cade (1990). Gyrfalcons left their natal areas between 15 August and 6 September (median $=27$ August \pm 6.4 days), but most left within a 2-week period in late August and early September. In contrast, Kessel (1989) observed that some Gyrfalcon families on the Seward Peninsula remained together well into September and October.

The mean post-departure bearings for Gyrfalcons from the Seward Peninsula and Denali were different (Watson's $U^{2} 50.31$, df $=26,14$, $P<0.005)$; Seward Peninsula Gyrfalcons tended to move to the southwest and Denali Gyrfalcons tended to move north and northeast. Kessel (1989) summarized observations of Gyrfalcons moving into and through the Seward Peninsula from mid-August at least through September, and at Little Diomede Island from late August to early September. Kessel (1989) also reported the eastward movement of Gyrfalcons at Little Diomede
Island, where the birds stopped to rest before flying eastward toward Wales on the western coast of the Seward Peninsula. Aside from these movements being generally southward, Kessel (1989) reported that these movements lacked consistent directional orientation and that most observations suggested a generally eastward movement of Gyrfalcons on the Seward Peninsula during autumn. Although our results corroborated Kessel's report (1989) that juvenile Gyrfalcons ranged across the western Seward Peninsula during late August and early September, most movements we observed in our study were westward to coastal areas in Alaska and to Russia.

We tracked 15 radio-tagged juvenile Gyrfalcons for an average of $70.5 \pm 28.1$ days postdeparture (range $=3-102$ days). Gyrfalcons moved from 105 to $4299 \mathrm{~km}$ during the entire tracking period and tended to move greater distances earlier in the post-departure period (Figure 1). Gyrfalcons from the Seward Peninsula and Denali moved similar distances during each successive two-week period $\left(F_{1,5}\right.$ $=0.32, P=0.57)$. The distance between Gyrfalcons and their natal nest at the last PTT transmission ranged from 105 to $3371 \mathrm{~km}$.

We documented a diversity of movement patterns of juvenile Gyrfalcons (Figure 1). Four of the 10 Gyrfalcons from Seward Peninsula crossed the Bering and Chukchi seas 5-30 days after departing their natal areas. One Gyrfalcon from the Seward Peninsula stopped on Little Diomede Island during its ocean crossing. Two Gyrfalcons from Seward Peninsula made round-trip flights between western Alaska and eastern Russia from 10-21 days after departing their natal areas; each bird spent 10-17 days in eastern Russia, then returned to western Alaska in early October and flew south to the Yukon-Kuskokwim Delta region.

Overall, Seward Peninsula Gyrfalcons tended to remain in western Alaska or eastern Russia with no movements into interior Alaska. Their 

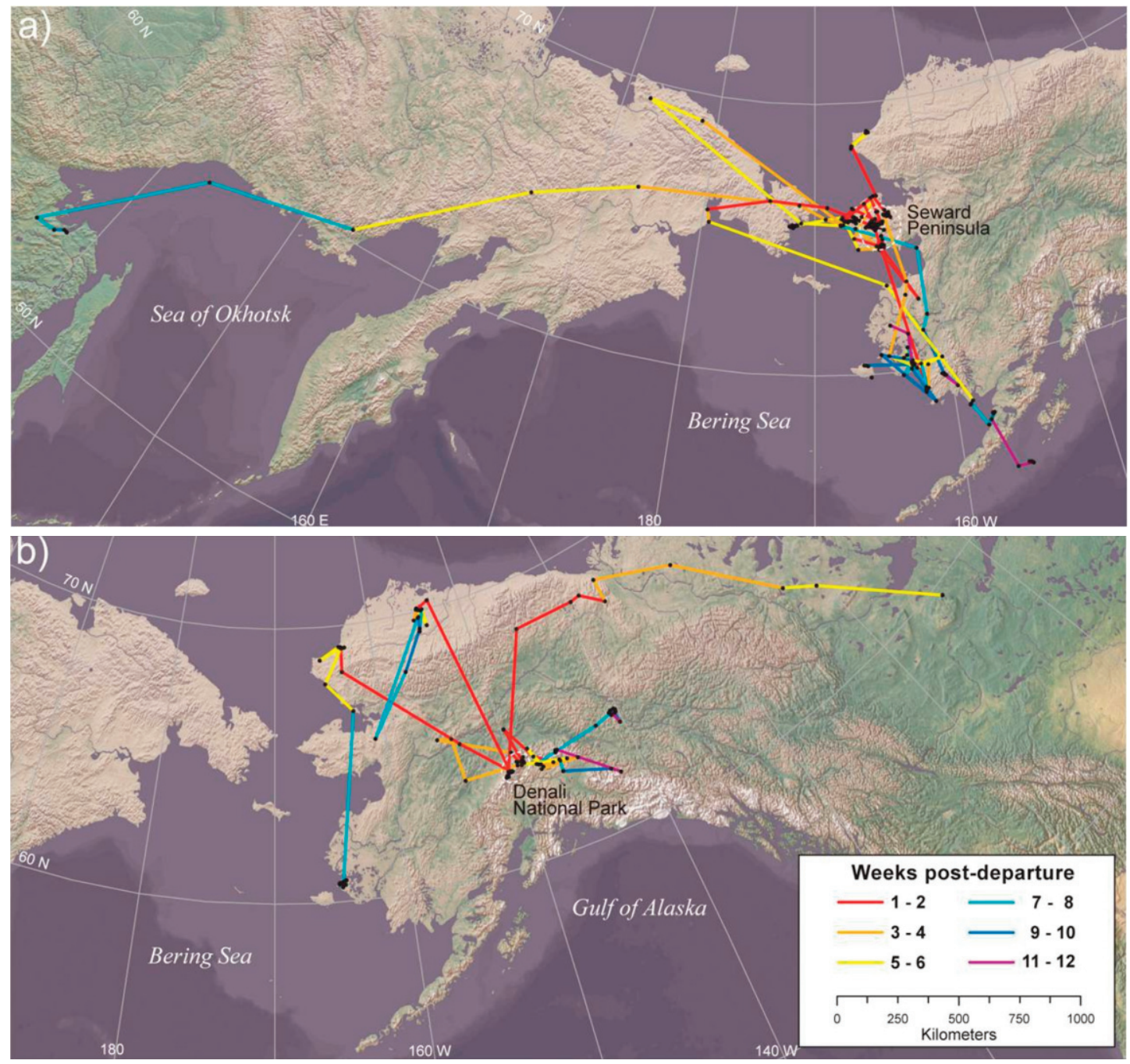

Figure 1. Movements of juvenile Gyrfalcons after leaving their natal areas on the Seward Peninsula (a) and Denali National Park (b), Alaska. Satellite tracking vectors are chronologically color-coded within 2-week intervals after departing natal areas for up to 12 weeks. White broken lines encompass study areas where Gyrfalcons were instrumented.

post-departure movements were diverse and included localized movements, round-trip ocean crossings, long distance movements into eastern Russia, and localized movements on the Seward Peninsula. In contrast, Denali Gyrfalcons flew to northern Alaska, western Alaska, northern Alberta, or remained in interior Alaska. All except one radio-tagged Gyrfalcon remained within the species' breeding range during the tracking period; one Gyrfal- con from the Seward Peninsula was located south of the documented breeding range for this species several weeks after leaving its natal area.

All Seward Peninsula Gyrfalcons and two Denali Gyrfalcons used coastal, wetland, or riparian habitats within one month of departing their natal areas. Two or more Gyrfalcons from different cohorts used several of the same 
coastal areas in western Alaska. Six Gyrfalcons from the Seward Peninsula were located on the northwest coast of the Seward Peninsula from late August through late September ( $\mathrm{N}=$ 1 bird in 1992, 5 birds in 1993). Coastal and wetland habitats in western and northwestern Alaska and eastern Russia, including the Seward Peninsula, Yukon-Kuskokwim Delta, Teshekpuk Lake and the Chukotka Peninsula appeared to be important to juvenile Gyrfalcons during the first few months of their independence. Cade (1960) also described regular autumn movements of Gyrfalcons in coastal Alaska including Kotzebue Sound, Cold Bay, and Kodiak Island. Juvenile Gyrfalcons in Iceland, where the dispersal distances were relatively short, and in Fennoscandia also moved to coastal areas in autumn and winter (see references in Nielsen and Cade 1990). Kessel (1989) also noted the movement of multiple Gyrfalcons across the northwestern coast of the Seward Peninsula in autumn (from late August through mid-September).

Wintering Gyrfalcons often concentrate in areas with high prey densities (Booms et al. 2008), and we suggest that the radio-tagged Gyrfalcons departed their natal areas when diversity and abundance of prey was decreasing and flew to areas where the diversity and abundance of prey was increasing. For example, coastal and near-coastal areas in western Alaska (i.e., Lisburne Peninsula, Seward Peninsula, Yukon-Kuskokwim Delta) and eastern Russia along the Chukchi and Bering seas support a large, diverse avifauna with globally significant breeding and wintering populations of seabirds (Sowls et al. 1978, Konyukhov et al. 1998, Hatch et al. 2000), substantial numbers of migrating waterfowl and shorebirds (Derksen et al. 1981, Gill and Handel 1990, Schmutz and Kondratyev 1995, Petersen et al. 2003), and substantial numbers of staging and wintering waterfowl (Phillips et al. 2006, Oppel et al. 2009). Coastal and riparian areas in western Alaska often support large concentrations of ptarmigan (Cade 1960, Weeden 1965).
Changes in the Arctic sea ice related to climate change (Valdés et al. 2009) will have tremendous cascading effects on Arctic and subarctic ecosystems including coastal and wetland areas. Increases in shipping (Corbett et al. 2010), oil and gas exploration (Fissel et al. 2009) and fishing (Stram and Evans 2009) will introduce new human activities into Gyrfalcon habitats, increase the potential for oil spills (Macdonald et al. 2003), and increase exposure to environmental contaminants (Letcher et al. 2009). Changes in sea ice may also affect the distribution, abundance, and availability of prey species such as seabirds (Tranquilla et al. 2010, Byers et al. 2010) and waterfowl (Chaulk et al. 2007, Loworn et al. 2009, Oppel et al. 2009). Additionally, small-scale wind power projects are currently generating electricity in remote coastal areas of western Alaska (e.g., Tooksook Bay, Wales, Pribilofs, and Kotzebue; Dabo 2008) and similar projects are being proposed for other coastal areas in western Alaska, including several areas used by the radio-tagged Gyrfalcons. Although these wind-powered energy projects are currently much smaller in size and scale than others in the United States (R. Ritchie, pers. comm.), it is important to identify the spatial and temporal movements of Gyrfalcons and other birds through these areas to avoid wind turbine strikes.

Our study demonstrated the efficiency of satellite tracking technology to identify movement patterns not previously documented, or postulated, for wide-ranging animals. For example, our most unexpected results included roundtrip flights across the Bering Sea and northward flights of birds that eventually moved southward; such movements would have been difficult to document without satellite tracking. While our results underscore the applicability of satellite telemetry for studying dispersal (Walters 2000), we highly recommend that researchers who are planning to use backpackstyle harnesses to attach tracking devices on Gyrfalcons conduct thorough evaluations to identify the long-term and cumulative adverse 
effects of the radio-package before implementing such studies. Satellite telemetry has allowed biologists to follow individual migratory birds and investigate their behavior, movement patterns, and seasonal distribution, but few studies have evaluated the cumulative and long-term effects of radio packages attached using backpack harnesses to raptors (see references in Steenhof et al. 2006). We could not determine the fate of radio-tagged Gyrfalcons but we suspect that the radio packages adversely affected the radio-tagged birds during the latter part of the tracking period when winter conditions set in and the radiotagged birds experienced additional stresses associated with decreasing prey abundance and increasing weather severity (freezing temperatures, freezing rain, and snow). Although contemporary telemetry units are much lighter and smaller than the PTTs we deployed, we agree with the recommendations of Steenhof et al. (2006) that researchers thoroughly investigate the possible impacts of radio-marking free-flying raptors by conducting treatment and control experiments before deploying PTTs on wild birds.

Results of this study highlight the wide-ranging movements of juvenile Gyrfalcons from two different study areas in Alaska. Conserving the habitat of wide-ranging animals is difficult and complex, particularly when animals range across international boundaries and live in areas that are undergoing rapid change resulting from the cascading effects of climate change and increasing human activities. Received 2 March 2011, accepted 12 April 2011.

McIntyre, C. L., D. C. Douglas, and L. G. Adams. 2011. Movements of juvenile Gyrfalcons from western and interior Alaska following departure from their natal areas. Extended abstract, pages 283-290 in R. T. Watson, T. J. Cade, G. Hunt, M. Fuller, and E. Potapov (Eds.). Gyrfalcons and Ptarmigan in a Changing World, Volume I. The Peregrine Fund, Boise, Idaho, USA. http://dx.doi.org/10.4080/gpcw.2011.0202.

Published in full as McIntyre, C. L., D. C. Douglas, and L. G. Adams. 2009. Movements of juvenile Gyrfalcons from western and interior Alaska following departure from their natal areas. Journal of Raptor Research 43:99-109.

\section{Literature Cited}

Alerstam, T. 1990. Bird Migration. Cambridge University Press, Cambridge, UK. ARGOS. 1996. User's manual. CLS/Service Argos, Toulouse, France, http://www.argossystem.org/manual (accessed 27 October 2008).

Booms, T. L., T. J. CAde, AND N. J. Clum. 2008. Gyrfalcon (Falco rusticolus). The Birds of North America Online (A. Poole, Ed.). Ithaca: Cornell Lab of Ornithology; Retrieved from the Birds of North America http://bna.birds.cornell.edu/bna/species/114
Byers, T., A. Smith, And M. L. Mallory. 2010. Diet of Black Guillemots and Northern Fulmars breeding beside a High Arctic polyna. Polar Biology 33:457-467.

CaCCAMise, D. F., AND R. S. Hedin. 1985. An aerodynamic basis for selecting transmitter loads in birds. Wilson Bulletin 97:306-318.

CAdE, T. J. 1960. Ecology of the Peregrine and Gyrfalcons populations in Alaska. University of California Publications in Zoology 63:151-290.

Chaulk, K. G., G. J. Robertson, and W. A. MonteVECCHI. 2007. Landscape features and sea ice influence nesting Common 
Eider abundance and dispersion. Canadian Journal of Zoology 85:301-309.

Corbett, J. J., D. A. Lack, J. J. Winebrake, S. Harder, J. A. Silberman, AND M. GoLD. 2010. Arctic shipping emissions and inventories and future scenarios. Atmospheric Chemistry \& Physics Discussions 10:9689-9704.

DABO, M. 2008. Regional economic development in rural Alaska, Part I - Identifying regional potential. Bethel Regional Wind Development Workshop, Alaska Energy Authority, Anchorage, Alaska, USA.

Derksen, D. V., T. C. Rothe, and W. D. ELDRIDGE. 1981. Use of wetland habitats by birds in the National Petroleum Reserve-Alaska. US Fish and Wildlife Service, Resource Publication 141.

Douglas, D. C. 2006. The Douglas Argos-Filter algorithm. http://alaska.usgs.gov/ science/biology/spatial/douglas.html (accessed 15 May 2008).

FisSEl, D. B., J. R. MARKo, AND M. MARTINEX DE SaAVEdra Alarez. 2009. Proceeding of the International Offshore \& Polar Engineering Conference, Osaka, Japan, June 21-26, 2009.

GiLl, R. E., JR., AND C. M. HANDEl. 1990. The importance of subarctic intertidal habitats to shorebirds: A study of the central YukonKuskokwim Delta, Alaska. Condor 92:709-725.

Hatch, S. A., P. M. Meyers, D. M. Mulchahy, and D. C. Douglas. 2000. Seasonal movements and pelagic habitat use of murres and puffins determined by satellite telemetry. Condor 102:145-154.

INSIGHTFUL. 2001. S-Plus Version 6.0 for Windows. Insightful Corporation, Seattle, Washington, USA.

KerLinger, P. 1989. Flight Strategies of Migrating Hawks. University of Chicago Press, Chicago, Illinois, USA.

Kessel, B. 1989. Birds of the Seward peninsula, Alaska. University of Alaska Press, Fairbanks, Alaska, USA.

Konyukhov, N. B., L. S. Bogoslovskaya, B. M. Zvonov, and T. I. Van Pelt. 1998.
Seabirds of the Chukotka peninsula, Russia. Arctic 51:315-329.

Kovach, W. L. 2003. Oriana - circular statistics for Windows, Version 2. Kovach Computing Services, Pentraeth, Wales, UK.

Letcher, R. J., K. V. Bustnes, R. Dietz, B. M. Jenssen, E. H. Jørgensen, C. Sonne, J. Verreault, M. M. Vijayan, and G. W. BABRIELSEN. 2009. Exposure and effects assessment of persistent organohalogen contaminants in arctic wildlife and fish. Science of the Total Environment 408:2995-3043.

Loworn, J. R., J. M Grebmeier, L. W. COOPER, J. K. Bump, AND S. E. Richman. 2009. Modeling marine protected areas for threatened eiders in a climatically changing Bering Sea. Ecological Applications 19:1596-1613.

Macdonald, R. W., T. Harner, J. Fyfe, H. LOENG, AND T. WEINGARTNER. 2003. AMAP Assessment 2002: The Influence of Global Change on Contaminant Pathways to, within, and from the Arctic. Arctic Monitoring and Assessment Programme (AMAP), Oslo, Norway.

McGrady, M. J., M. Ueta, E. R. Potapov, I. UteKhina, V. MASTEROV, A. LADYGUine, V. Zykov, J. Cibor, M. Fuller, AND W. S. SEEGAR. 1997. Movements by juvenile and immature Steller's Sea Eagles Haliaeetus pelagicus tracked by satellite. Ibis 145:318-328.

McIntyre, C. L., D. C. Douglas, And M. W. Collopy. 2008. Movements of Golden Eagles (Aquila chrysaetos) from interior Alaska during their first year of independence. Auk 125:214-224.

McIntyre, C. L., D. C. Douglas, and L. G. ADAMs. 2009. Movements of juvenile Gyrfalcons from western and interior Alaska following departure from their natal areas. Journal of Raptor Research 43:99-109.

Newton, I. 1979. Population Ecology of Raptors. Buteo Books, Vermillion, South Dakota, USA.

Newton, I. 2008. The Migration Ecology of Birds. Academic Press, London, UK. 
Nielsen, O. K., AND T. J. Cade. 1990. Annual cycle of the Gyrfalcon in Iceland. National Geographic Research 6:41-62.

OpPel, S., D. L. Dickson, AND A. N. Powell. 2009. International importance of the eastern Chukchi Sea as a staging area for migrating King Eiders. Polar Biology 32:775-783.

Petersen, M. R., B. J. McCaffery, And P. L. FLINT. 2003. Postbreeding distribution of Long-tailed Ducks Clangula hyemalis from the Yukon-Kuskokwim Delta, Alaska. Wildfowl 54:103-113.

Phillips, L. M., A. N. Powell, ANd E. A. ReXstad. 2006. Large-scale movements and habitat characteristics of King Eiders throughout the nonbreeding period. Condor 108:887-900.

Poole, K. G., AND R. G. Bromley. 1988. Natural history of the Gyrfalcon in the central Canadian arctic. Arctic 41:31-38.

Schmutz, J. A., AND A. Kondratyev. 1995. Evidence of Emperor Geese breeding in Russia and staging in Alaska. Auk 112:1037-1038.

Schmutz, J. K., R. W. Fyfe, U. BANAsch, AND H. ARMBrUSTER. 1991. Routes and timing of migration of falcons banded in Canada. Wilson Bulletin 103:44-58.

Sowls, A. L., S. A. HATCH, AND C. J. LENSINK. 1978. Catalog of Alaska seabird colonies. Unpublished report. US Fish and Wildlife Service, FWS/OBS-78/78, Anchorage, Alaska, USA.

Steenhof, K., K. K. Bates, M. R. Fuller, M. N. Kochert, J. D. MCKinley, AND P. M. LUKACS. 2006. Effects of radiomarking on Prairie Falcons: Attachment failures provide insight about survival. Wildlife Society Bulletin 34:116-126.

Steenhof, K., M. R. Fuller, M. N. Kochert, AND K. K. BATES. 2005. Long-range movements and breeding dispersal of Prairie Fal- cons from southwest Idaho. Condor 107:481-496.

Stram, D. L., AND D. C. K. Evans. 2009. Fishery management responses to climate change in the North Pacific. ICES Journal of Marine Science 66:1633-1639.

Swem, T., C. Mcintyre, R. J. Ritchie, P. J. Bente, and D. G. Roseneau. 1994. Distribution, abundance, and notes on the breeding biology of Gyrfalcons Falco rusticolus in Alaska. Pages 437-444 in B.-U. Meyburg and R. D. Chancellor (Eds.). Raptor conservation today: Proceedings of the IV World Conference on Birds of Prey and Owls. World Working Group on Birds of Prey and Owls, Berlin, Germany, and London, UK.

Tranquilla, L. M., A. Hedd, C. Burke, W. A. Montevecchi, P. M. Regular, G. J. Roberton, L. A. Stapleton, S. I. WilHelm, D. A. Fifield, AND A. D. Buren. 2010. High Arctic sea ice conditions influence marine birds wintering in Low Arctic regions. Estuarine Coastal and Shelf Science 89:97-106.

Valdes, L., W. Peterson, J. Church, K. BRANDER, AND M. MARCOS. 2009. Our changing oceans: Conclusions of the first International Symposium on the effects of climate change on the world's oceans. ICES Journal of Marine Science 66:14351438.

Walters, J. R. 2000. Dispersal behavior: An ornithological frontier. Condor 102:479481.

WEEDEN, R. B. 1965. Alaska wildlife investigations: Grouse and ptarmigan in Alaska; Their ecology and management. Alaska Department of Fish and Game, Fairbanks, Alaska, USA.

Welty, J. C. 1963. The Life of Birds. W.B. Saunders Co., Philadelphia, PA, USA. 